\title{
University Entrepreneurship Education System Design Based on Two-way Drive
}

\author{
( SUBMITTED BUT NOT PRESENTED)
}

\author{
FENG Guan \\ College of Information Science and Technology \\ Bohai University \\ Jinzhou, China \\ fengguan@126.com
}

\author{
XING Yanhui \\ Student Development and Affairs Center \\ Bohai University \\ Jinzhou, China
}

\begin{abstract}
Nowadays public business innovation is looked as a new engine of economic development of China. In order to adapt to the change of environment and the demand of society, many universities have opened the course of entrep reneu rship education successively. The entrepreneurship education in most Chinese Universities is government-driven, employment-oriented. This kind of education cannot reflect the students' initiative and cannot meet the needs of the students. This article puts forward a university entrepreneurship education system designing based on two-way driver. This system has the characters such as two-way drive, targeted; hierarchical design, distributary training; rich curriculum, complete system. At the last, it offers some problems which should be paid attention to.
\end{abstract}

Keywords-entrepreneu rship education; education system; twoway drive

\section{OVERVIEW OF UNIVERSITY ENTREPRENEURSHIP EDUCAT ION}

In 2014, Premier Li Keqiang on Sept 10 delivered a speech at the opening ceremony of the Annual Meeting of the New Champions 2014, also known as the Summer Davos Forum. He said:" I believe the key to realizing that is to further liberate our mind, further liberate and develop the creativity of society, further energize businesses and the market, and remove all institutional obstacles to development so that everyone interested in starting a business is given more space for entrepreneurship and the blood of innovation could flow unhampered in a society where everyone is full of the spirit of self-development. When reform and innovation fuels the massive wave of entrepreneurship by the people and at the grassroots level on the land of the 9.6 million square kilometers of China, the enormous power of the diligent and resourceful Chinese people will be fully unlocked and the engine driving China's sustained economic development will constantly regenerate itself and remain powerful. " Promoting public business innovation is becoming a national strategy.

In 1999, the "21st Century Education Revitalization Action Plan" issued by the Ministry of Education stated:" Strengthen entrepreneurship education to teachers and students, encourage them to customize the founder of high-tech enterprises." Since then, Entrepreneurship Education began to enter the national university, a lot of scholars made a useful exploration of entrepreneurship education and research achieved positive results. Entrepreneurship education of Chinese universities has the following characteristics:

A. reach a broad consensus on the meaning of

Entrepreneurship education in colleges and universities

In recent years, the significance of entrepreneurship education in colleges and universities reached a broad consensus that promoting entrepreneurship education in colleges and universities, both from an economic and social development, or the development of higher education, or the overall development of students, is of great significance. " number of major issues of CPC Central Committee on deepening reform of the overall" November 12, 2013 Eighteenth Communist Party of China Central Committee of the Third Plenary Session, in advancing the cause of social reform and innovation that read: "sound system to promote employment and entrepreneurship mechanism "," the implementation of incentive policies for college graduates start their own businesses, the integration of the development of national and provincial employment of college graduates venture capital fund "has been interpreted more strategic level guidance for university innovation and entrepreneurship education.

\section{B. the Chinese University entrepreneurship education is government-driven, employment-oriented}

In May 2011, the State Council issued the "The Notice of Circular on Further Improving the work of universities and colleges graduates." Notification made to encourage and support college graduates starting their own businesses. Colleges and universities required to carry out widespread entrepreneurship education, develop innovation and entrepreneurship courses actively, improve entrepreneurship education curriculum and make the entrepreneurship education courses into credit management. The Ministry of Education announced, by the end of 2012, of the "general undergraduate school entrepreneurship education teaching basic requirements (Trial)" on the website, which provides business -oriented basic course will become compulsory for all students individually opened, colleges and universities also offer business conditions contained Practical Course Education elective courses. Entrepreneurship education will eventually be incorporated into the training systemof colleges and universities. 


\section{Chinese universities entrepreneurship education system is the lack of entrepreneurship education curriculum system}

Our entrepreneurship education courses lack systematic plan, there are also serious deficiencies of targeting and operability, etc. Entrepreneurship education developed by some universities is out of touch with the basics of professional disciplines, cannot play discipline the advantage. Entrepreneurship education courses in addition to "business basis", the mostly belong to the "career planning", "career guidance", etc. There is no system of independent entrepreneurship education curriculum system. As for the choice of materials on entrepreneurship education, there are two common practice of University: One of them is using the foreign direct translation entrepreneurship textbook, causing the serious divorce between the contents of textbooks and the practice of the Chinese market; the other is sorting fragmented business case home and abroad out and booklet printing, resulting teaching content was too "factual", and was lack of universal laws of refining entrepreneurial activ ity and universal significance.

\section{Low entrepreneurship proportion of Chinese college students, high failure rate}

In 2010, a survey shows that entrepreneurs receiving college enterprise education entrepreneur in the tertiary industry accounted for 89.46 percent, while who did not receive college enterprise education entrepreneurs the proportion of tertiary industry was $85.73 \%$ This set of data shows that the contribution of entrepreneurs received entrepreneurship education in the country's industrial structure adjustment and upgrading of only slightly larger than other entrepreneurs. According "Employment Blue Book (2010 Chinese University Employment)" by MyCOS company, in the survey, at "211 Schools" who is attaching great importance to entrepreneurship education overall, the proportion of graduates in business were $0.5 \%, 0.54 \%, 0.4 \%$ in 2007,2008 , 2009.

Based on this, it believes that the system of enterprise education should not only be limited to meet the needs of government employment-oriented design, but also should take full account of the objective needs of the students' undertaking; not just chasing the competition results, the rate of students' entrepreneurs and other utilitarian indicators ,but should considering the impact of entrepreneurship education on students' thinking, awareness and the entrepreneurial behavior in the future; not just the sake of discussion or a mere formality, but should be combined with professional education, and the integration of innovative education. Only by this way to improve the effectiveness of entrepreneurship education effectively, to achieve national venture to promote entrepreneurship, entrepreneurship to create jobs in the strategic plan, to meet the needs of entrepreneurial activity of college students.

\section{BI-DRIVEN ENT REPRENEURSHIP EDUCATION SYSTEM DESIGN}

\section{A. The general framework}

The general framework of $\mathrm{Bi}$-driven entrepreneur education system is shown in Fig. 1, the main features are: two-way drive, targeted; hierarchical design, distributary training; rich curriculum, complete system.

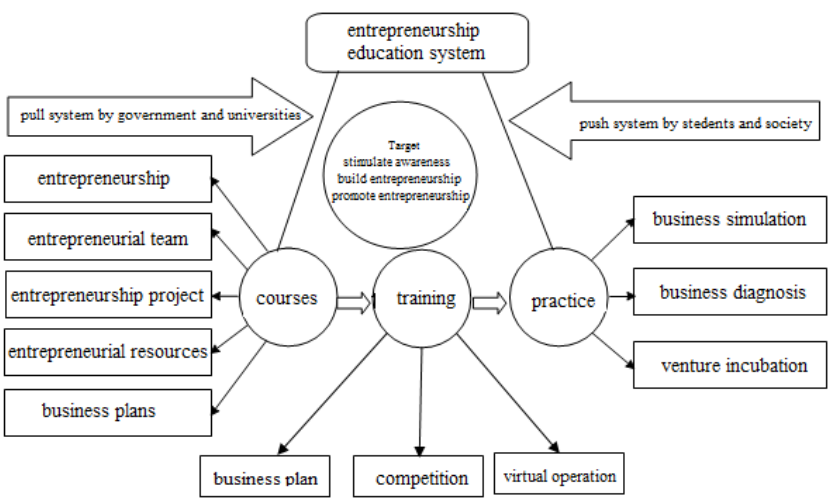

Fig. 1

\section{B. System Introduction}

\section{1) Two-waydrive, targeted a) two-way drive}

The "bi-drive-based entrepreneurship education system design" is using bidirectional drive which including the government and universities leading to promote entrepreneurship education system and students and social needs stimulating entrepreneurship education system:

Entrepreneurship education promoting system leaded by Government and universities based on social and economic development, the requirement of schools' entrepreneurship education for development of higher education, adds entrepreneurship education really into the training system of higher education, increases enthusiasm and initiative of entrepreneurship education in colleges and universities, so that universities can treat entrepreneurship education from a strategic point of view, and make sure the requirements of education authorities at all levels effectively to do real entrepreneurship education.

Students' and social demand pull system based on requirements of students' and social needs for colleges and universities to carry out entrepreneurship education, opens entrepreneurship education courses in line with students and social development needs, improves students' enthusiasm and initiative to participate in the entrepreneurship education, makes enterprise education the real from the student-centered point of view and meet the students' and social realities demand for enterprise education, improves the effectiveness of entrepreneurship education in colleges and universities effectively.

b) Targeted

Bidirectional driven entrepreneurship education system intends to change the current situation that innovation and entrepreneurship education is sake of discussion or a mere formality now, designs the university's innovation and 
entrepreneurship education system to meet of the socialist market economic system needs, by setting different levels of innovation and entrepreneurship curriculum system and training program, individualized, and improve the effect of innovation and entrepreneurship education effectively. So that innovation and entrepreneurship education embodies the objective requirements of "student oriented", and can take up the requirements to train quality personnel for an innovative nation-building, and truly inspires of college students' innovation consciousness, shapes college students' entrepreneurship, improves the undergraduates' ability of undertaking.

\section{2) Hierarchical design, distributary training}

With "business basis" added in undergraduate compulsory, innovation and entrepreneurship education once again become the focus of educational research. What entrepreneurship education talks and how to speak also caused widespread concern in the field of higher education. To carry out a business education well, we need to classify students according to the needs of them. Bidirectional driven entrepreneur education system taking into account the different needs of students for entrepreneurship education, is divided entrepreneurship education into three from low to high level (shown in Fig. 2).

The first level, for all students, the creation of business foundation courses were designed to stimulate students' awareness of entrepreneurship, general education of universal theory of entrepreneurship. By setting such courses, on the one hand, universities can complete the requirements of the universities to offer entrepreneurship curriculum by relevant government administrative departments and introduce government policies for business students, plants seeds of entrepreneurs in the college students' minds; on the other hand, universities can also complete the research of students' basic quality of entrepreneurship and business knowledge needs, to provide effective support for the development of education at next two levels.

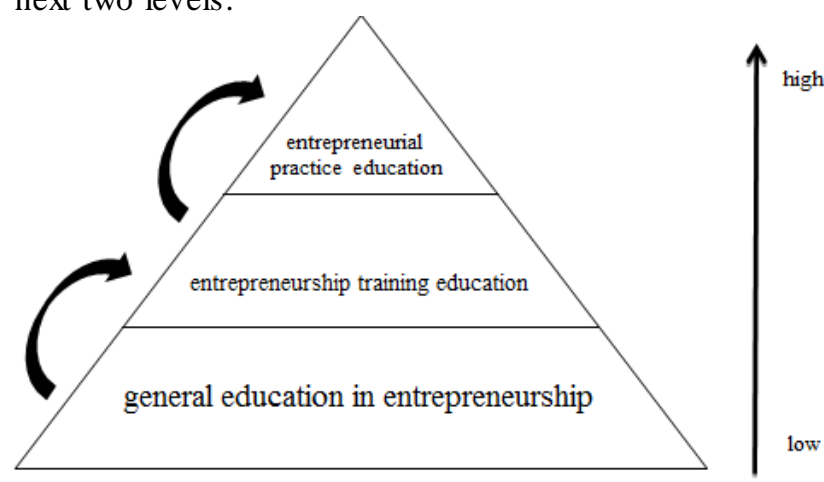

Fig. 2

The second level, for the students have a strong will and entrepreneurial potential, sets entrepreneurial training program courses which can enhance their entrepreneurial capacity. The second level students' chosen should combine the wishes of individual students, based on the assessment of the first level course, for the purpose to enhance students' entrepreneurship and entrepreneurial insight. Through entrepreneurship training, it can concise the students constantly business ideas and improves entrepreneurial ready.

The third level, for the good start preparing students who have discovered entrepreneurial opportunities, sets up various types of practical business practice course for developing students' innovation and entrepreneurship ability to use, with project activities for guidance and the combination of teaching and practice, strengthens guidance to students venture in a targeted manner, while by providing universities business incubators, gives the appropriate support to possible venture projects for fighting for hatching, landing opportunity and guides students to entrepreneurial behavior actively.

\section{3 ) Rich curriculum, complete system}

Entrepreneurship basic course mainly lecture on "entrepreneurship and entrepreneurial spirit", "entrepreneurs and entrepreneurial team", "Entrepreneurial Opportunities and projects," "business resources and entrepreneurial environment", "business model and business plan" modules, can be taken by different forms such as teaching, lecture, online classes and so on.

Entrepreneurship training courses mainly focus on the business plan to start, through guiding students writing a business plan and learning networks and virtual operation course, to participate in business plan competition and network virtual operator contest. Students are encouraged to experience all aspects of the business ready, including business market assessment, business finance, entrepreneurship and risk management processes, which can further enhance the students' perceptions of business operations, hone entrepreneurial team, and enhance the practical ability and entrepreneurial ability of students to participate in business operations management.

Venture combat mainly works around how to build an entrepreneurial enterprise, through the virtual business venture projects to identify problems and make entrepreneurial diagnosis. For the adequate demonstration program can be given opportunity to the Incubation, really starting to shape students' Entrepreneurship, entrepreneurial practice and generate entrepreneurial behavior.

\section{THE PROBLEM SHOULD BE PAID ATTENTION TO}

\section{A. Recognize entrepreneurship education from national development strategies height}

Entrepreneurship education should be placed on the height and strategic level. On August 1, 2012, the General Office of the Ministry of Education issued a notice on the issuance of "general undergraduate school entrepreneurship education teaching basic requirements (Trial)", the Document states: enterprise education in colleges and universities is strategic initiatives to serve countries to speed up the transformation of economic development mode, to build an innovative nation and strong human resources, is important approach to deepen the reform of higher education and improve the quality of personnel training, and promote comprehensive development of students, is important measures to implement entrepreneurship to employment, and promote full employment of college graduates. 


\section{B. Establish a large business ideas}

Nowadays public business innovation is looked as a new engine of economic development of China. In this environment universities should set a big education of innovation and entrepreneurship.

Entrepreneurship education should not only be to train students to create a new corporate as objective of education, should determine non-utilitarian goal to cultivate students' innovative spirit, creativity, entrepreneurship awareness and entrepreneurship as the core, the teacher is fire-broadcast, presenters, coaches of entrepreneurship education, should ignite the torch of student entrepreneurs, plant the seeds of entrepreneurship in the minds of students and enable students to master the method of innovation and entrepreneurship. Should not simply consider the number of student entrepreneurs entities, the winner number when students participate in entrepreneurship class competition or business success of the project as the evaluation of University Innovation Entrepreneurship Education Quality Standards.

\section{Explore the integration ofentrepreneurship education and professional education}

Innovation and entrepreneurship education is the organic composition of professional education, is the innovative, forward-looking embodies of professional education in the knowledge economy, is the inevitable choice for higher professional education and deepening teaching reform. Innovation and entrepreneurship education should never be the skills training activities which was separated from professional education, but should be the training program with professional education, including teaching concept and mode during the whole theory and practice teaching process. Education is the basis of the theory and practice of innovation and entrepreneurship education, innovation and entrepreneurship education which has professional knowledge as a support for is firm and full of vitality, based on this, the university should explore the pattern in which innovation and entrepreneurship education and professional education is organic fusion according to the school situation.

\section{Entrepreneurship education should adhere to openness}

Entrepreneurship education in universities should insist on the principle of openness, in order to maintain the vitality and vigor, cause the student's interest and meet the needs of students, entrepreneurship education must adapt to social development and changes in the market. Open entrepreneurship education on the one hand is the performance of that enterprise education is inseparable from society and the market: entrepreneurship education in universities can make use of social resources, business counseling, set up venture capital fund; the selection of universities venture is subjected to market testing; the effect of University Entrepreneurship Education needs society and identity verification. On the other hand, openness of entrepreneurship education performance that enterprise education offers intellectual support for social entrepreneurship, which means entrepreneur education resources open to the public, social entrepreneurship knowledge and courses can be obtained from Colleges and Universities.

\section{CONCLUSIONS}

In order to adapt to the change of environment and the demand of society, it is necessary to conduct entrepreneurship education in colleges and universities. It should be based on the school situation, relying on the advantages of existing resources. In this sense, a university should explore innovation and entrepreneurship education model of its own. However, innovation and entrepreneurship education in universities cannot take administrative guidance, university-led model. Universities innovation and entrepreneurship education must adhere to the idea of "student-centered" and "driven by student demand", consider the students' future career development, career pioneering real needs, with full respect for the entrepreneurship students' vision of innovation. It's the only way that universities innovation and entrepreneurship education can meet the expectations of the state and society Universities innovation and entrepreneurship education truly, and achieve positive educational outcomes.

\section{REFERENCES}

[1] Common colleges and universities innovation and entrepreneurship education steering committee in liaoning province, "Know about business" Beijing, HigherEducation Press

[2] Yin Qi, Cao Xiu-ping, Zhu Jun-nan, "Entrepreneurship education system design and the formation of the dual education in colleges and universities", Journal of Liaoning University of Technology(Social Science Edition), 2009(6), pp. 93-96.

[3] Li Keqiang, Creating New Dynamism Through Reform and Innovation[R], the World Economic Forum Annual Meeting of the New Champions 2014, 10 September 2014, TianJin, china http://english.gov.cn/premier/speeches/2014/09/22/content_2814749885 75784.htm 